\title{
高度なる左顏面部瓣狀象皮病を件へろレックリング ハウゼン氏病の一症例に就て
}

朝鮮本壤聯合基督病院耳鼻咽喉科

栤

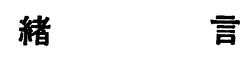

1882年フォン・レツクリングハウゼン氏が皮

膚結節狀腫㾤は种經鞘及び內神經䩪の結締織よ り生ずるものにして，惡性の朴經腫，多發性林 經腫, 蔓狀科經腫等皆同一系統的疾患なり之唱 へし以來，多くの學者之に贊し本病を以て所謂 レツクリングハウゼン氏病と别称するに至れり. その後本病の研究郝告は多くは皮虚科, 外科少 至神經科方面に於て數多く追加せられたり.之 が耳算咽喉科の交涉に關しては本病の一症状と

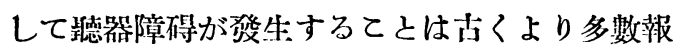
告せられたるも，耳舅科に關する限り余の涉獵 せる文獻の範圍にては显野呚授が臨床丵義に於

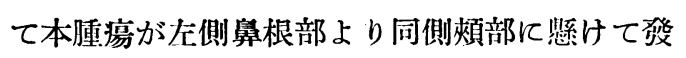
生せる症例を鄁義せる外未だなし. 余も亦最近

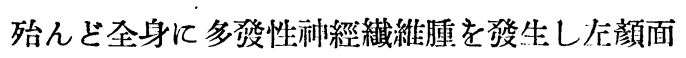

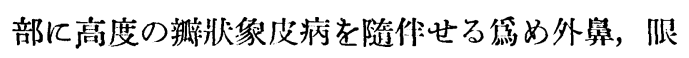
憸，上唇等は诘だしき醜版を是し目直性臭奥を 有する本病例を經驗したるに你り茲に報告せん とす.

\section{症例}

患者 000,71 歲, 女子, 無職.

主訴 嗅覺障碍, 助血.

家族史 父は患者15歲の時不叨の疾患にて擎れ，目 は70歲を越して老衰死亡すと. 同胞 3 人小姉は 50 歲の 時急死し(心藏㾋瘏?) 妹は健在なり.夫は彼女の30歲 の時原因不明の疾患にて死す. 子女 3 人を安產せしも 2 人は天折し，末子は10年前行方不明. 其の他家族及
近親にして患者に見るが如き疾患に罹りし者なく，精 种病的並に榊經疾患的遗傅も證せられず.

䀢往症 幻時天然症を俓く經過せる外，生來極めて 强健にして著忠を知らず.16歲の時結婚，19歲の時に 初經來潮し，以來順調にして46歲に至り閉止す. 外伤,

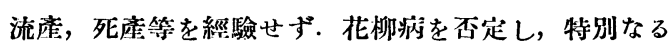
㗪好品を有せず。

現病歴 20歲の時左顴骨突起面下部に緊張感及び蛊 接を感じ，第めに揾抓摩擦を反復し該部表皮肥厚せり． 斯くの如き狀態數件間繼續山，或る時計らずも該部皮 下に約母指頭大の膘物埋没せるを觸知せるも，前記癌

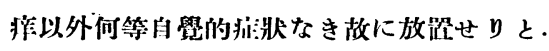

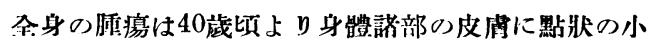

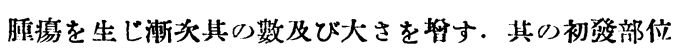
及び其後の發生顺庉に就きては記憶する所なし，該䛲 瘳は初めより自發痛又は医痛等なく何等苦痛を感ぜざ りしと云ふ.

現在症 體格は川等度, 皮下脂䏚組織及び筋肉の發

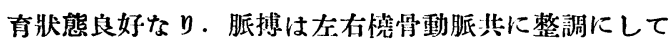
緊張中等度なり。血厭 Max. 152, Min. 82. 頭部, 毛

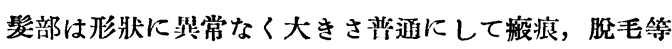
を證し得ず、腰椎は輕废の前们を呈し，四肢骨路に異 常を衿めず. 到部，腋下，肘部等の淋巴腺婳脤なし。

心臟、界は左第3 胁骨, 左界は左㑬乳腺, 右界は

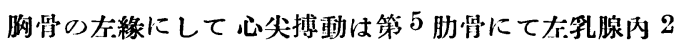
横指の所に在り.五解知せらる.

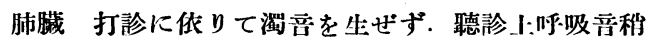
々籶雜なる外異常なし.

腹部 腹壁他緩し硬度正常, 表面本滑にして凸.厚痛

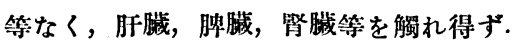

眼左眼は」:眼瞼の著しき下垂の俘め眼球全く見元 ず．之を瞅轉して檢するに眼球全面に黄色膿樣分泌物 を附着す．之を洗㹋して見るに絬膜充血及们膜洞濁し

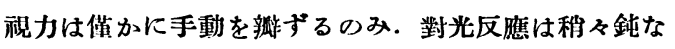

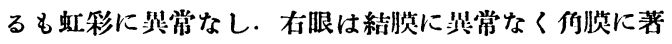


明の老人環存し，反射正常にして視力障碍なし. 眼球 運動は兩眼共に正常なり。

口膑＼cjkstart茼牙は㱠んど脱落し下颚右大臼茲 1 個のみ. 舌は舌苔等なく運動自由なり，咽頭，口蓋扁桃腺等に 變化なく粘膜には脏湯, 斑點等を認めず.

耳 左右の耳款，外㯖道に異常なく鼓膜に認む可き 變化なし. 㯖力は左右共に尋常にして傅害器, 感音器 共に正常. 他の腦神經檢查，視神經，動眼神經，猾事 种經，外旋神經，䫈面神經，舌咽种經，迷走神經，舌 下神經等は機能正常にして何等の障碍なし，但し㭡覺 は全然缺如し，三叉神經領域の左頝面腄瘍部に於ての 感覺は右に比し稍々鈍なり。

精神狀態 指南力, 注意力, 記憶力等尋常にして殊 に注意力，聽力等は非常に賢察なり。

互反應陰性に乙て便いに蛔蟲，鞭䖵の卵を認むる 外, 其の他腦春咀液, 血液像, 尿, 膝蓋腱反射等に認 む可き變化を有せず。

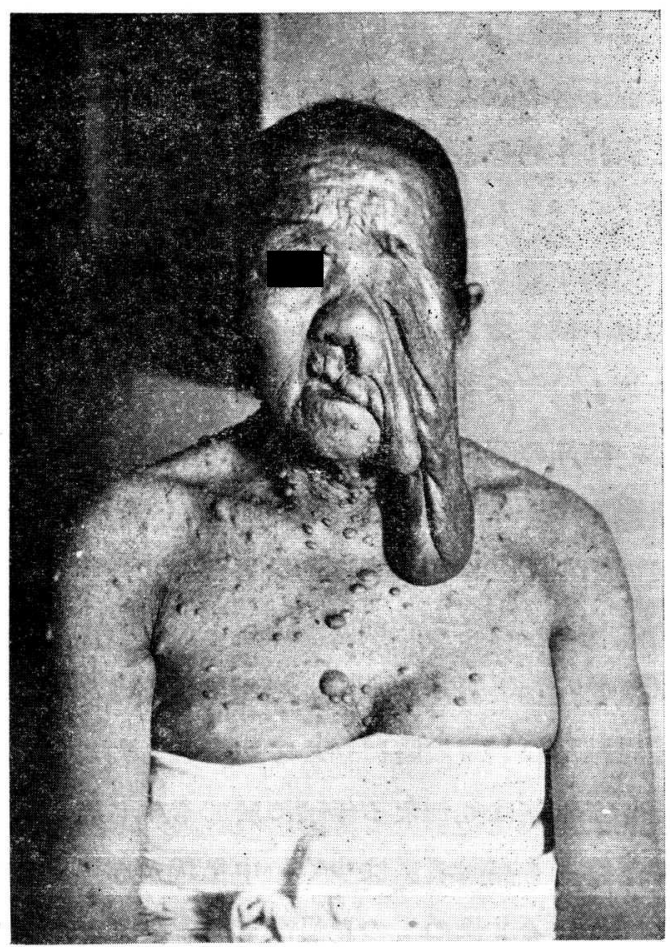

局所々見 額面を見るに左鼻根部, 左上眼瞼及左顴 骨部等上り始まり左胸部迄に至る漂簕狀を成したる 2

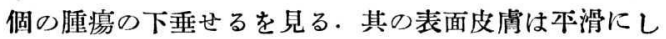
て稍肥厚緊張し，所々に色素沈着の斑點を有す. 該腫 大の上下徑は $18 \mathrm{~cm}$, 左右徑は $9 \mathrm{~cm}$ にして, 上界は顴
骨弓を超えて漱次不明となり，右は鼻杜及び鼻唇满を 以て竟となし，後部は左开珠近くに及び下は左鎖篔部

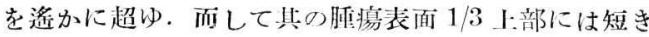
硬毛を生ず、触るつに胜瘙中央部は稍々鈍感なるも一 般に知覺に異常なく几柔きが川にも，皮下に於て索狀 物質积橫に走行し，所々に核樣物質を形成して恰も淋 巴腺の連なるが如きものを觸知す．厴によりて疼痛を 訴ふる事なく搏動を證せず，且之を䝠縮する事能はず．

鼻 外鼻は此腄場の篇め著しき戀形を呈し，鼻梁は 陷凹目扁平にして低下す，左鼻翼は上部脸隆し下部は 藷しく肥大下垂して鼻尖と殆んど识何に曲り其の上下 徑は $2.2 \mathrm{~cm}$ ，左右徑は $2.0 \mathrm{~cm}$ を等す，其の皮膚面は 毛孔能く發達し周圍との境界は明瞭ならず，脂肪に触 るつが如く柔軟にして皮下に翼狀軟骨を有せず，鼻院 内を檢するに兩側共綠黄色の結㘯を以て充塞せられ名 狀すべからざる惡臭を放つ，之を取り去るに鼻腔は其 常廣濶となり，鼻粘膜は暮白色を呈し菲薄にして甲介 萎縮甚だしく殊に左側は僅かに下甲介部が其の痕跡を 殘すのみ。

左眼裂は本蕾㽽の第め著しく延長され其の長さ $7 \mathrm{~cm}$ なり．父上原は左口何部に於て外下方に移動され口裂 は顯著に左右和對性を失ふ。

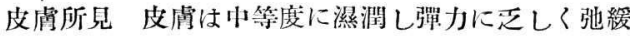
す. 小腫瘍は殆んど全身に播種狀に散在し其の數日算 にても1000個以上なり．最も多き部は項部及禹翰にし て次で頻面，頭部等なり。四胶殊に前膊及下肢には非 常に少なく，一般に未梢に至る程少なくして手，下腿， 足部等には㱠んぞなく，手掌，足蹠には全くなし，大 さは肉眼にて辛じて見得る程度のものより䲴卵大位に 至る迄種々の大さのもの混在す，色は小なるものは皮 虔の色と同じく大なるものは多くは暗褐色を呈す，形 は牛球形のもの多く，其の基底は廣く，孤立せるもの 大部分なるも 2 倜以上融合せるものあり．厚痛又は自 發痛なく知覺障碍もなし：硬度は非常に軟く稍彈力性 を有す。沿皮虞面には所々に喑褐色の色素沈着を認め 形は不正形の斑狀及ど點狀のもの混在さ。周图と著明 に區劃し厚痛なし，其の發生部位は腫瘍之略ぼ一致す。 上線騫䧟に依机ば顔面骨部は凡て正常なり。

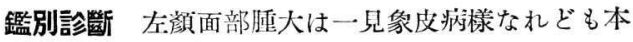

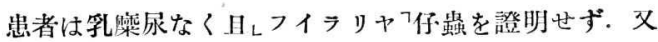
象皮病は皮虞が著しく硬度を㬝すものにして決して本 患者の如く柔軟ならず，日斯かる疾患の多き地方的關 係全然なし、之に加ふるに皮虐に於ける色素斑及び結 
節の存在は蓝々之に一致せず．次に本患者の皮庙の結

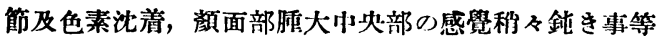

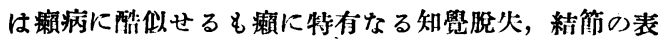

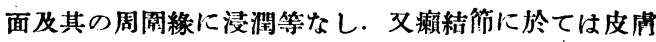
扁平隆起は一種の油狀光摆を有し月.I:哏穼种經，尺骨

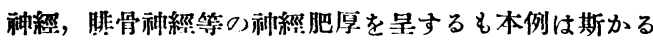
事なし．又前記の所見及び鑑別診尉等上り推すときは 頻面部腫大は勿論炎病性のものにあらず，又搏動を缺 き月之を厭縮する事能はず，其の皮下に大小の結節及 び索佟物を觸れ，非常に長き經過を取りたる等の誟點 を綜合するに惡性堙瘍又は血管縢等をも行易に除外し 得. 故に之は一種の良性蕾瘍に外ならず，又全身皮虐 К見らる〉無數の異常に軟かき卅球狀の降起も之を腫 场と見る可きものなり．而も大體に於て色素斑と其に 神經蟣維の走行之略低一致せる多數性の腫瘍なり。

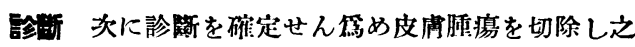
をしフォルマリンフ夜固定しパフフインフ包埋の下に切片 を製ししへマトキシリンフ及ワイゲルト氏染色を施して 、檢せり．表皮には著變なく之と腰瘍組織とは緙密なる

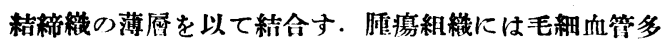

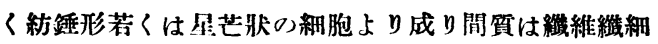

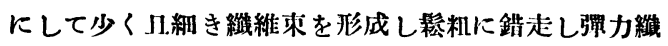
維は極めて少し，

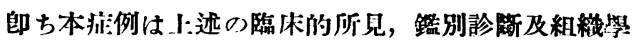

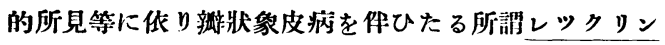

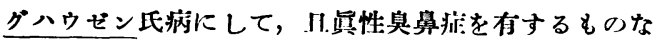
马.

療法 峂性臭鼻病の療法を施す修らレックリング八 ウゼン氏病に對しては頝面部腫瘍の摘出を勸めたりし る患者來訲の目的主訴にあり几高齢の故を以て肯んぜ ษ゙.

\section{總括並に考按}

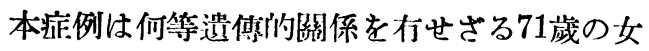
子にして庄顴骨弓より始まりたる腫瘍が約50年 間の長期に涉り漸次俈大して其の上下徑 $18 \mathrm{~cm}$, 左右徑 $9 \mathrm{~cm}$ の大さとなり彯管狀を成して下垂 せるに的り同側の外舅，眼憸及び上唇に著しき 變形を呈せり．全身皮虞には新。゙て肉哏にて兄 得る程度のものより鳩卵大に至る種々の大さの 腫瘍播種狀に散在し且點狀，斑归の巴素沈清を

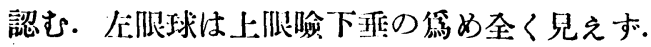

之を䕁轉して檢するに角膜溷濁し視力障碍を有

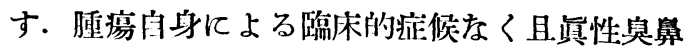

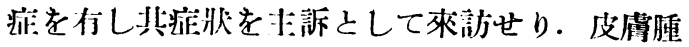

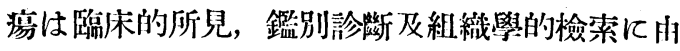

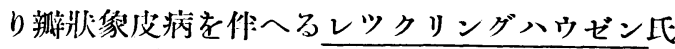
病なることを癸抈せり。

抑 こレツクリングハウゼン氏病として皮膚表 面に多發する种經纎維腫は沈して稀なるものに

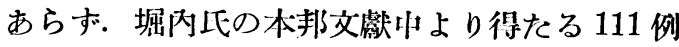
の統梓成績により余の症例を論ぜん。

性别及遭㑛に關しては男71例，女40例にして 刃丁・に多く遗傅の詠し得へきものは全數の $1 / 3$ と云へり. 然れども余の例は女子ににて遗傳的 關係を認め得す。，皮㲊の結甪については其の數 は數千の多數より數十穴滿たざるものあり．若 し夫れ本病の不全型と称すへきものにありては 逐に一個をも證し得ず。勾子に於ては中川氏の 5404 個が最も多く，女子に於ては高田氏の 400 個以上例を最上とす，余の例は優に 1000 個を超 ゆるを以て女子に於ける最上のもの之云ひ得へ し. 結䈃の分布は如何なる部分にも來り得れど 8最も多きは軀幹, 頸部にして顔面, 頭部, 四 肢の順なり. 本例も项部に最も多し. 皮虔結䈔 の最初に現はるる時期は 20 藏以下が最も多く,

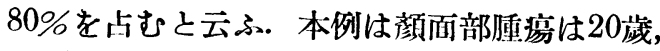
皮膚結簡は40藏の時に初めて生ぜしものなり。 而して本病は如何なる年莑命に於ても生じ得るも のなれども高給者には少く，中島氏及び中川氏 の65歲なる 2 例のものを最高とす. 然れども余 の症例は71歲の高峂令に於けるものなり．又本症 例の如く多發性利經纎維腫几作ひ瓣状像皮病を 發生せるものは內外を通じて比較的少く，本邦 飞於ては若山，三㑔，河村氏の郝告を仯するの 
み. 而して文本症例の如く顏面部に生じたる該 腫瘍が㠿だ大にして，之が第め外鼻，腿噞，上 唇等に著しき變形を是せるものは極めて其例少 きものと思はる。

元來本病の隨伴症候として智的並に精相的障 碍多く，本邦の文獻飞於ても智的發育不充分之 記されたるもののみにても31例を數ふ. 然れど も精神の優秀なる者も稀化非らず. 余の例名之

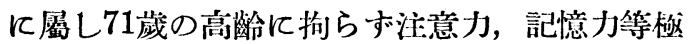

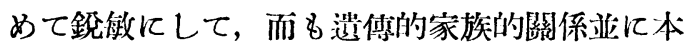
病の誘因之認む可き事項を有せず。斯くの如き 症例に遭遇するに於ては本病の原因を把握する 事益々困難なるを痛感せしむ。

又文獻に徵するに本病は嗅朴經と視神經とに 稀なれど繊維性變化を示すことあるも，アドリ アン氏は解剖的變化を伴はずして㬇鹠並に祝學 に變化ある數例を述べたり．余の例は嗅學消失
を來せるものなれど高度の眞性葸悬症を有する 第め其の何れが眞因なるや審かならず，又本病 と臭性臭舅症との相互關係如何に對しては兩者 共に其の原因適確なりとは云ひ難き今日此の 1 例のみにては何れとも云くするの徐地なし．本 例の視覺に關しては視力右眼は正常なるに反し 左眼著しく琵へたるは分泌物刺戟に依る角膜溷 濁の䉆めなるべし.

\section{結論}

1）本症例は造傅的關係を有せざる71歲の女 了・にして，左颜面部に高度なる瓣彇像皮病を伴 ひたるレツクリングハウゼン氏病の 1 例なり.

2)左颜面部該腫瘍の䉆め同側の外悬，眼憸 及び上唇は些だしき變形を呈す。

3）本症例は㯖性臭鼻症を併有す。

稿を終るに臨み，恩阨星野㸚授の御想篤なる御校閱に 滿腔の謝意を表す。

\section{文㓺}

1）星野：开鼻臨，第19焱，第2號.

2）黑田：大川开鼻，第45焱，第9號.

3）松山：皮有之泌尿， 第7卷, 第 3 號.

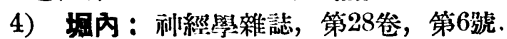

5) 秋間：皮遊科泌汖器科雜誌, 第 45 卷, 第5號.

6) 大矢：紫界展望，第246號.

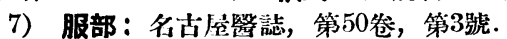

8) 杉立： 日本整形外科誌，第14焱，第1號.

9）高崎：皮虙科紀娎，第34焱，第5 5 號.

10) 河村：日本外科誌， 第13卷，第2號. 11）苨山：日本外科誌，第 14 卷，第 1 號. 第2號.

13) 小出：神經學雜誌，第16焱. Anderson: Journal of amer. m. A., Vol. 74, Nr. 15, 1920.

14)
12）上條，中島：种經學雜誌，第22卷， 橋本：東京䝷誌，第2卷，第22號.

16) Wieder Henry : Z. blatt. Bd. 20, 1933.

17) Adrian : Z. blatt. f. d. Grenzgeb. d. Med. u. Cir. 1903.

18) Neuman : Z. blatt. f. Hals usw. 1927. 